\title{
Molecular diagnosis of the brown root rot disease agent Phellinus noxius on trees and in soil by rDNA ITS analysis
}

\author{
Yong-Feng Wang ${ }^{1,2}$, Han Meng ${ }^{2}$, Victor W. Gu ${ }^{3}$ and Ji-Dong $\mathrm{Gu}^{2 *}$ \\ ${ }^{1}$ Guangdong Provincial Key Laboratory of Bio-control for the Forest Disease and Pest, Guangdong Academy of For- \\ estry, No. 233, Guangshan 1st Road, Guangzhou, People's Republic of China \\ ${ }^{2}$ Laboratory of Environmental Microbiology and Toxicology, School of Biological Sciences, The University of Hong \\ Kong, Pokfulam Road, Hong Kong SAR, People's Republic of China \\ ${ }^{3}$ Chinese International School, 1 Hau Yuen Path, Braemar Hill, Hong Kong SAR, People's Republic of China
}

\begin{abstract}
Phellinus noxius (P. noxius) is an important pathogen that causes brown root rot of trees in tropical and subtropical areas and has led to severe damage to trees. A quick and accurate diagnostic technique is essential to the timely confirmation of the pathogen and possible treatment. In this study, a fast, sensitive and accurate approach of molecular technique was used to diagnose the brown root rot pathogen on trees and in soils of subtropical Hong Kong. Two pairs of specific PCR primers were used to amplify the target rDNA internal transcribed spacer (ITS) region through polymerase chain reaction (PCR) for both tree tissues and soil samples. The amplified ITS fragments were then sequenced and analyzed phylogenetically for the diagnostic identification of the pathogen $P$. noxius. The results showed that 13 of 38 suspected trees in Hong Kong were infected with $P$. noxius through molecular detection. The pathogen showed no specific preference to any particular tree species. Quantitative PCR was applied to soils grown with trees identified both positive and negative for $P$. noxius, but the soils with healthy trees were also found positive for $P$. noxius. For the first time, $P$. noxius was reported to infect a wide range of tree species in Hong Kong and widely presented in soils, probably serving as a reservoir for the pathogen. Through this study, it is proposed that $P$. noxius is a soil-borne pathogen, which increases $i$ ts infectivity whe $\mathrm{n}$ rees s tart $\mathrm{t}$ o gr ow in the soil a s a m eans i $\mathrm{n}$ a ddition $\mathrm{t}$ o the pr eviously proposed root-to-root contact.
\end{abstract}

Keywords: Phellinus noxius, molecular diagnosis, brown root rot

*Correspondence to: Ji-Dong Gu, Laboratory of Environmental Microbiology and Toxicology, School of Biological Sciences, The University of Hong Kong, Pokfulam Road, Hong Kong SAR, People’s Republic of China; Email: jdgu@hku.hk

Received: June 22, 2015; Accepted: February 1, 2016; Published Online: April 8, 2016

Citation: Wang Y-F, Meng H, Gu V W, et al. 2016, Molecular diagnosis of the brown root rot disease agent Phellinus noxius on trees and in soil by rDNA ITS analysis. Applied Environmental Biotechnology, vol.1(1): 81-91. http://dx.doi.org/10.26789/AEB.2016.01.002.

\section{Introduction}

$\mathrm{T}$ The fungus Phellinus noxius ${ }^{[1]}$ is a pathogen that is responsible for the not orious brown root rot of landscape, orchard, and forest trees. This fungus has a wide range of hosts including more than 200 species in 59 families $^{[2]}$, and since then more new tree species h ave a lso been a dded to this 1 ist $^{[3,4]}$. D espite favoring woody trees, $P$. noxius can also attack some herbaceous $\mathrm{pl}$ ants ${ }^{[2,5,6]}$. P. noxius has be en $\mathrm{f}$ ound in many tropical and subtropical countries and di stricts, including Singapore, Japan, Indonesia, Malaysia, Hai-

Molecular diagnosis of the brown root rot disease a gent Phellinus noxius on trees and in soil by rDNA ITS analysis. (C) 2016 Yong-Feng Wang, et al. This is an Open Access article distributed under $t$ he term $s$ of the Creativ e Commons Attribution -NonCommercial 4. 0 I nternational $L$ icense (http://creativecommons.org/licenses/by- nc/4.0/), permitting all non -commercial use, distribution, and reproduction in an y medium, provided the original work is properly cited. 
nan Island in China, Macao, Taiwan, Africa, Australia, Central America, and the Caribbean ${ }^{[3-19]}$. The wide geographical distribution of this pathogen and the severe da mage it ha s caus ed have d rawn significant concerns.

Conventional diagnosis of brown root rot caused by $P$. noxius involves in obs erving symptoms and isolating the $p$ athogen from di seased tissues ${ }^{[2,4]}$. T rees infected with $P$. noxius normally pr esent w ilting a nd discoloring of foliage ${ }^{[13]}$. The exposing roots and basal stem a re of ten encrusted with a la yer of y ellowishbrown, brown, or brownish-black mycelial mat ${ }^{[13]}$. The inner surface of the infected bark is usually white with brown networks ${ }^{[2]}$. P. noxius can be i solated from infected tissues on malt-extract a gar (MEA) medium amended by Chang ${ }^{[20]}$. Brown colonies can be formed on potato dextrose agar (PDA) medium accompanied by i rregular da rk brown lines or patches ${ }^{[2]}$. A lthough the traditional method is frequently applied to identify brown root rot caused by $P$. noxius, it is not quite reliable a nd practical. Firstly, ot her pathogens $m$ ay produce s imilar symptoms which might 1 ead to w rong conclusion $^{[21]}$; se condly, $P$. noxius cannot always be obtained from the infected tissues through c ulturing; thirdly, the isolation process normally takes a long time, which may delay timely treatment.

Although several measures have been developed to control this pa thogen ${ }^{[22-24]}$, a qui ck and accurate $\mathrm{di}$ agnosis is the requisite condition for timely treatment. Therefore, a qui ck and reliable di agnosis is urgently needed. Molecular assay is a fast, sensitive and reliable method to identify P. noxius ${ }^{[25,26]}$. In this method, a pair of s pecific $P C R$ primers were us ed t o a mplify rDNA internal transcribed spacer (ITS) fragments, the sequences of $w$ hich $c$ an be s ubsequently a pplied to compare with the know $\mathrm{s}$ equences of $P$. noxius on GenBank database. Through $\mathrm{t}$ his way, $\mathrm{t}$ he $\mathrm{p}$ athogen can be identified as $P$. noxius or otherwise.

A qui ck a nd a ccurate di agnosis is c ritical to t reat brown root rot of individual cases. It is also important to make clear the mechanism of dissemination approach of this pathogen to prevent the spread of brown root rot induced by $P$. noxius. However, the di ssemination a pproach of $P$. noxius pathogen is s till und etermined $\mathrm{d}^{[2,3]}$. Currently, the dominant view is that this pathogen s pread through r oot-to-root co ntact ${ }^{[2,3]}$, but no solid evidence has been given.

$P$. noxius has not been reported in subtropical Hong Kong. H owever, our pr eliminary experimental da ta showed that some landscape trees in Hong Kong had been infected with $P$. noxius. In this study, we applied molecular $t$ echnique $t$ o i dentify $b$ rown root $r$ ot i nfected with $P$. noxius. F irstly, the la ndscape tr ees in parks and roadsides around Hong Kong were scanned and then suspicious trees were sampled for molecular analysis in lab. For the first time, we determined the occurrence of $P$. noxius and their ge ographical distribution i $\mathrm{n} \mathrm{H}$ ong $\mathrm{K}$ ong. $\mathrm{B}$ esides $\mathrm{t}$ he di agnosis of $P$. noxius in Hong Kong, we explored their dissemination mechanism by investigating the occurrence of $P$. noxius in soils. Through this investigation, we proposed that $P$. noxius probably s pread $t$ hrough both pa thogen-containing soil and root-to-root contact.

\section{Materials and Methods}

\subsection{Wood and Soil Samples Collecting}

From October 2013 t o F ebruary 20 14, a 11 the 1 andscape trees ov er Hong Kong were inspected by ga $\mathrm{r}-$ deners trained with the know ledge of brown root rot. Suspicious $t$ rees $r$ eported $b$ y g ardeners $w$ ere $t$ hen sampled by members in our laboratory. A total of 38 suspicious trees were sampled (one tree was collected twice and another one were collected thrice). For each suspicious tree, at 1 east $3 \mathrm{w}$ ood $\mathrm{s}$ amples at different directions of the $t$ ree, w eighting 5-10 g each, w ere collected aseptically from the roots and/or basal stem. The wood samples were then transported the same day to lab for genomic DNA extracting.

Soils be tween a de ad tree a nd a di seased tree caused by Phellinus noxius in $\mathrm{K}$ owloon $\mathrm{P}$ ark w ere collected. The dead tree had already been removed on the day of s oil collecting. The $t$ wo trees w ere $15 \mathrm{~m}$ apart an $\mathrm{d}$ soils be tween the $\mathrm{t}$ wo trees were col lected every $2 \mathrm{~m}$. A total of 9 soils were collected (including 2 soils at the basal stems of the two trees). Another 5 soils under trees that were not infected with $P$. noxius were also collected. Among these 5 soils, 2 soils were under T ree008 a nd T ree036; a nother 3 soils, w hich were named HKU soil1, HKU s oil2, and HKU soil3, were under three healthy trees on campus of The University of Hong Kong. HKU soill and HKU soil2 were both under tree species Ficus microcarpa, but in different places; HKU soil3 $\mathrm{w}$ as under tree s pecies Bauhinia sp.

\subsection{Total Genomic DNA Extraction}

For wood samples, the extraction protocol was revised from Ding et al. ${ }^{[27]}$. Briefly, $0.5 \mathrm{~g}$ of the wood tissue was $\mathrm{cut}$ from the $\mathrm{s}$ ample. The $\mathrm{w}$ ood $\mathrm{t}$ issue $\mathrm{w}$ as then 
washed with Milli-Q water three times and blot dried. The dry tissue $w$ as then put into a sterile mortar and frozen b y liquid ni trogen $\left(-196^{\circ} \mathrm{C}\right)$ a nd gr ound i nto powder. A bout $0.2 \mathrm{~g}$ of the pow der w as then $\mathrm{t}$ ransferred into a sterile $1.5 \mathrm{~mL}$ Eppendorf tube for subsequent DNA ext raction. The total DNA w as ext racted with E.Z.N.A ${ }^{\circledR}$ Forensic D NA ki t ( Omega B io-Tek, USA) according to the manual of the manufacturer.

For s oil s amples, $0.25 \mathrm{~g}$ of $\mathrm{s}$ oil $\mathrm{w}$ as w eighted for DNA extraction. T he soil $\mathrm{w}$ as extracted in duplicate using t he P owerSoil ${ }^{\circledR}$ DNA is olation kit ( MO BI O Laboratories, In c. U SA) a ccording to the manual of the manufacturer, which was demonstrated to produce ideal $r$ esult el sewhere ${ }^{[28,29]}$. T he dupl icate D NA e xtractions from the same soil sample were then pooled together and stored at $-20^{\circ} \mathrm{C}$ for subsequent molecular analysis.

\subsection{PCR Amplification}

The genomic DNA extracted from the w ood samples were amplified using the primer pair PN-1F (5' - AGTTTGCGCTCATCCATCTC - 3') and PN-2R (5' - AGCCGACTTACGCCAGCAG $\left.-3^{\prime}\right)^{[25]}$. T he opt imized polymerase chain reaction (PCR) mixture contained in a final volume of $50 \mu \mathrm{L}$ was as the following: $1 \mu \mathrm{L}$ of DNA $\left(20 n g \mathrm{~L}^{-1}\right), 10 \mu \mathrm{L}$ of $5 \times$ GoTaq Flexi buffer (Promega, Hong Kong) and $4 \mu \mathrm{L}$ of $\mathrm{MgCl}_{2}(25 \mathrm{mM}$, Promega), $1 \mu \mathrm{L}$ of dNTPs (10 mM of each, Promega), $1 \mu \mathrm{L}$ of e ach forward a nd reverse p rimers $(20 \mu \mathrm{M})$

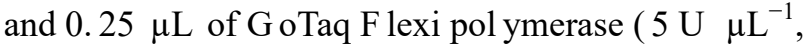
Promega), $5 \mu \mathrm{L}$ of BSA ( $0.1 \%)$. PCR conditions were set as follows: $95^{\circ} \mathrm{C}$ for $3 \mathrm{~min} ; 30$ cycles of $95^{\circ} \mathrm{C}$ for $45 \mathrm{~s}, 60^{\circ} \mathrm{C}$ for $45 \mathrm{~s}$, followed by $72^{\circ} \mathrm{C}$ for $1 \mathrm{~min}$; and finally $72^{\circ} \mathrm{C}$ for $10 \mathrm{~min}$.

When using $\mathrm{P}$ N-1F/PN-2R to amplify ta rget fragments from genomic DNA of soils, only smear bands were formed. But when utilizing the primer pair G1-F (5' - GCCCTTTCCTCCGCTTATTG - 3') and G1-R $\left(5^{\prime} \text { - CTTGATGCTGGTGGGTCTCT }-3^{\prime}\right)^{[26]}$, the PCR result $\mathrm{w}$ as much better. $\mathrm{T}$ herefore $\mathrm{G} 1-\mathrm{F} / \mathrm{G} 1-\mathrm{R}$ wa $\mathrm{s}$ used to amplify soil genomic DNA in this study. The optimized PCR r eaction mixture contained in a final volume of $50 \mu \mathrm{L}$ was as the following: $1 \mu \mathrm{L}$ of DNA (20 ng $\mu \mathrm{L}^{-1}$ ), $10 \mu \mathrm{L}$ of $5 \times$ G oTaq F lexi buffer (Promega, Hong Kong) and $4 \mu \mathrm{L}$ of $\mathrm{MgCl}_{2}(25 \mathrm{mM}$, Promega), $1 \mu \mathrm{L}$ of dNTPs (10 mM of each, Promega), 1 $\mu \mathrm{L}$ of each forward and reverse primers $(20 \mu \mathrm{M})$ and $0.25 \mu \mathrm{L}$ of GoTaq F lexi polymerase $\left(5 \mathrm{U}^{-1} \mathrm{~L}^{-1}\right.$, Promega), $5 \mu \mathrm{L}$ of BSA $(0.1 \%)$. PCR conditions were set as follows: $94^{\circ} \mathrm{C}$ for $4 \mathrm{~min} ; 38$ cycles of $94^{\circ} \mathrm{C}$ for $45 \mathrm{~s}$, $56^{\circ} \mathrm{C}$ for $45 \mathrm{~s}$, followed by $72^{\circ} \mathrm{C}$ for $45 \mathrm{~s}$; and finally $72^{\circ} \mathrm{C}$ for $10 \mathrm{~min}$.

PCR products were checked by electrophoresis in a $1 \%$ agarose gel stained with GelRed ${ }^{\mathrm{TM}}$ (Biotium, Hayward) at $1: 10,000$. The target gene fragments by PN1F/PN-2R a nd G 1-F/G1-R w ere 414/422 and $645 /$ $651 / 653$ bp long respectively. If the result of gel check is positive, the PCR products were then purified using Gel A dvance ${ }^{\mathrm{TM}}$ Gel E xtraction System (Viogene-Bio Tek Co., Taiwan, ROC) and subsequently sent for sequencing. If the sequencing quality was not desirable (e.g. the PCR product was not a single clone), a clone library was then constructed.

\subsection{Cloning and Sequencing}

When a clone library was ne eded, the p urified products w ere 1 igated into the pMD18 T-vector ( Takara, Japan) and then transformed into the host Escherichia coli competent cell DH5 $\alpha$ (Takara, Japan) in accordance with the manufacturer's instructions. A total of $5-10 \mathrm{c}$ lones were randomly s elected for culturing in solution. P lasmid D NA was s ubsequently e xtracted from the culturing solution. The target gene in the extracted plasmid DNA w as then sequenced with $\mathrm{ABI}$ 3730xl DNA Analyzer (Applied Biosystems).

\subsection{Phylogenetic Analysis}

The ret rieved sequences $w$ ere ana lyzed against those in $\mathrm{G}$ enBank with B LAST ${ }^{[30]}$. Af ter c himeric check and a ligned, all the sequences w ere cropped to 360 / 368 bases long to construct the ph ylogenetic tree u sing MEGA, version 5. $1^{[31]}$. Some sequences from other s tudies w ere do wnloaded from GenBank as reference. The sequence of Phellinus lamaoensis was used as $t$ he out gr oup. The ph ylogenetic $t$ ree $w$ as co $n-$ structed w ith the ne ighbor-joining method with 1000 bootstraps to e stimate the confidence of the $t$ ree $t o-$ pologies.

\subsection{Quantitative Real-time PCR Analysis}

The abundances of Phellinus noxius ITS genes in the soils between a dead tree and an infected tree in Kowloon $\mathrm{P}$ ark were de termined in qua druplicate with qu antitative real-time PCR a mplification using S YBR ${ }^{\circledR}$ Premix Ex Taq ${ }^{\mathrm{TM}}$ II (Tli RNaseH Plus) (Takara, Japan). Real-time qP CR w as pe rformed i n 96 -well opt ical plates placed in the ABI PRISM ${ }^{\circledR} 7000$ Sequence Detection System (Applied Biosystems). The primer set 
composed of G1-F and G1-R was used for the amplification of target genes. The final reaction volume was $20 \mu \mathrm{L}$ and the reaction composition and cycling conditions were in accordance with the manual.

The s pecificity of the $\mathrm{PCR}$ a mplification $\mathrm{w}$ as determined by the melting curve and the gel electrophoresis. Cycle thresholds were determined by comparing with the standard curves constructed using a $10 \mathrm{f}$ old serial di lution $\left(10^{2}-10^{7}\right.$ gene copi es $\left.\mu \mathrm{L}^{-1}\right)$ o f ne wly extracted plasmids cont aining ITS $g$ ene $f$ ragments. Relative c opy nu mbers a mong $t$ arget groups w ere evaluated and some replicates of apparent discrepancy were excluded in order to decrease standard error. The correlation coefficient $R^{2}$ value was greater than 0.99 for the standard curve.

\subsection{Scanning Electron Microscope Sample Prepa- ration}

The diseased root samples were fixed in $0.2 \mathrm{M}$ sodium cacodylate for about 24 hour s. The fixative $w$ as prefiltered through a $0.2 \mu \mathrm{m}$ p ore s ize cel lulose a cetate membrane $\mathrm{f}$ ilter ( $\mathrm{T}$ oyo Roshi $\mathrm{K}$ aisha $\mathrm{L}$ td., J apan). Samples w ere then rinsed with Milli-Q w ater three times. T he s amples were d ehydrated in an ethanolMilli-Q water series of 40, 60, 70, 80, 85, 90, 95 and $100 \%$ ethanol $^{[32]}$. Samples were stored in $100 \%$ ethanol at $4^{\circ} \mathrm{C}$ before further treatment. The samples were cold air-dried a nd then c oated $\mathrm{w}$ ith go ld-palladium and vi ewed und er the H itachi S -4800 field e mission scanning electron microscope.

\subsection{Nucleotide Sequence Accession Numbers}

The r DNA I TS s equences a re available in GenBank under accession numbers KM251804 to KM251851.

\section{Results}

\subsection{The Distribution of Phellinus noxius in Hong Kong}

A total of 38 suspected trees were sampled and diagnosed with molecular technique from October 2013 to February 2014 in Hong K ong ( Table 1 ). T hirteen of the $t$ rees were confirmed for infection by $P$. noxius after PCR amplification of the ITS regions of the pathogen in tree $t$ issue s amples collected from va rious trees. M ost i nfected t ree s pecies w ere Ficus microcarpa; a nother $\mathrm{t}$ wo were Celtis sinensis and Khaya senegalensis. No specificity to a selected group of tree species $\mathrm{c}$ an be as certained in this study. The infected trees we re di stributed i n di fferent di stricts i n $\mathrm{H}$ ong
Kong w ithout a ny apparent $\mathrm{p}$ attern or concentration (Figure 1).

\subsection{Symptoms and Ultrastructure of Diseased Tis- sue Infected with Phellinus Noxius}

The brown root rot caused by $P$. noxius was normally encrusted with a layer of mycelial mat that presented brown or dark brown on surface of roots in this study (Figure 2A ). S canning e lectron microscopic ( SEM) micrographs showed that the surface of the mycelial mat was covered with a layer of substance so that no hyphae could be seen clearly (Figure 2B), but unidentified ba cteria $c$ ould be found on $t$ he $s$ urface of the mycelial mat of the tree tissue. The pathogen may invade the host tissues and reside inside without showing a pparent morphological $f$ eatures of $t$ he $f$ ungus. Hyphae are capable of penetrating into the wood cells, and the hyphae can also form branches during growth (Figure 2C and 2D). U nknown ba cteria can also be found coexisting with $P$. noxius in the diseased tissues (Figure 2C and 2D).

\subsection{Phylogeny of Phellinus noxius}

PCR a mplified ITS DNA s equences of $P$. noxius obtained from the tree tissues sampled in this study were analyzed. The ph ylogenetic tree of $P$. noxius showed that $t$ he majority of $t$ he $s$ equences $r$ etrieved in $t$ his study $\mathrm{h}$ ad known related sequences al ready obt ained in other countries or districts, except those in Clade 5 (Figure 3), so the pathogen is similar to those reported elsewhere and local previously. The di stribution pattern of $P$. noxius showed that the same clade included sequences f rom di fferent $\mathrm{c}$ ountries or $\mathrm{d}$ istricts i ndicating their wide spread. Clade 1 includes sequences obtained from $\mathrm{T}$ aiwan, $\mathrm{H}$ ainan of $\mathrm{C}$ hina, $\mathrm{M}$ alaysia, and Hong Kong of China in this s tudy (Figure 3 ). Another phenomenon was that the sequences from the same sample can fall into different clades. For example, s equences obt ained from $\mathrm{T}$ ree $003 \mathrm{fell}$ into bot $\mathrm{h}$ Clade 2 a nd $\mathrm{Clade} 3$; s equences obtained from Tree009 fell into both Clade 1 and Clade 3; and sequences obtained from Tree 027 fell into Clade 1, Clade 3, and Clade 5 (Figure 3 ). It seems that $P$. noxius is a pa thogen $w$ ith 1 ittle di vergence a cross a 1 arge ge ographic region but at the same time the va riation a mong the region can be 1 ocalized on a pa rticular $t$ ree $t$ issue. Such observation may be related to the survival strategies and a lso di ssemination means us ed by the $\mathrm{pa}$ thogen. 
Table 1. Information of suspicious trees and results of molecular diagnosis

\begin{tabular}{|c|c|c|c|c|c|}
\hline Tree code & Collecting Date & Tree species & Location & OVT $^{\Delta}$ No. & P. noxius \\
\hline Tree001 & $21 / 10 / 2013$ & Celtis sinensis & Kowloon Park & Non OVT & Yes \\
\hline Tree002 & $24 / 10 / 2013$ & Ficus microcarpa & Lei Yue Mun Park & LCSD E/4 & Yes \\
\hline Tree003 & $24 / 10 / 2013$ & Khaya senegalensis & Lai Chi Kok Park & Non OVT & Yes \\
\hline Tree004 & $24 / 10 / 2013$ & Khaya senegalensis & Lai Chi Kok Park & Non OVT & Yes \\
\hline Tree $005^{*}$ & $29 / 10 / 2013$ & \multirow{3}{*}{ Ficus microcarpa } & \multirow{3}{*}{ Kowloon Park } & \multirow{3}{*}{ LCSD YTM/65 } & \multirow{2}{*}{ Yes } \\
\hline Tree039* & $10 / 02 / 2014$ & & & & \\
\hline Tree $006^{\#}$ & $29 / 10 / 2013$ & & & & \\
\hline Tree $028^{\#}$ & $02 / 01 / 2014$ & \multirow[t]{2}{*}{ Ficus microcarpa } & \multirow[t]{2}{*}{ Kowloon Park } & \multirow[t]{2}{*}{ LCSD YTM/97 } & \multirow[t]{2}{*}{ Yes } \\
\hline Tree $038^{\#}$ & $10 / 02 / 2014$ & & & & \\
\hline Tree007 & $30 / 10 / 2013$ & Melia azedarach & Kwai Tsing & Non OVT & No \\
\hline Tree008 & $21 / 11 / 2013$ & Ficus microcarpa & Pokfield Road & $\mathrm{LCSD}$ CW/4 & No \\
\hline Tree009 & $26 / 11 / 2013$ & Ficus microcarpa & Hong Kong Observatory & Non OVT & Yes \\
\hline Tree010 & $11 / 12 / 2013$ & Ficus virens var. sublanceolata & Former Central Government & LCSD CW/95 & No \\
\hline Tree011 & $11 / 12 / 2013$ & Heteropanax fragrans & Former Central Government & LCSD CW/96 & No \\
\hline Tree012 & $11 / 12 / 2013$ & Ficus microcarpa & Hong Kong Park & LCSD CW/107 & No \\
\hline Tree013 & $11 / 12 / 2013$ & Ficus virens var. sublanceolata & Hong Kong Park & LCSD CW/108 & No \\
\hline Tree014 & $11 / 12 / 2013$ & Ficus elastica & Hong Kong Park & LCSD CW/109 & No \\
\hline Tree015 & $19 / 12 / 2013$ & Ficus microcarpa & Nathan Road & LCSD YTM/21 & No \\
\hline Tree016 & $19 / 12 / 2013$ & Ficus microcarpa & Nathan Road & LCSD YTM/22 & No \\
\hline Tree017 & $19 / 12 / 2013$ & Ficus microcarpa & Nathan Road & LCSD YTM/27 & No \\
\hline Tree018 & $19 / 12 / 2013$ & Ficus microcarpa & Nathan Road & LCSD YTM/28 & No \\
\hline Tree019 & $19 / 12 / 2013$ & Ficus microcarpa & Nathan Road & LCSD YTM/29 & No \\
\hline Tree020 & $23 / 12 / 2013$ & Ficus microcarpa & Nathan Road & LCSD YTM/1 & No \\
\hline Tree021 & $23 / 12 / 2013$ & Ficus microcarpa & Nathan Road & LCSD YTM/17 & No \\
\hline Tree022 & $23 / 12 / 2013$ & Ficus microcarpa & Nathan Road & LCSD YTM/19 & No \\
\hline Tree023 & $23 / 12 / 2013$ & Ficus microcarpa & Lo Wai Road & $\mathrm{LCSD} \mathrm{TW} / 3$ & No \\
\hline Tree024 & $23 / 12 / 2013$ & Ficus microcarpa & Tsing Yi Park & LCSD KTW/9 & No \\
\hline Tree025 & $23 / 12 / 2013$ & Ficus microcarpa & Tsing Yi Park & LCSD KTW/10 & No \\
\hline Tree026 & $02 / 01 / 2014$ & Mangifera indica & Hong Kong Park & Non OVT & No \\
\hline Tree027 & $02 / 01 / 2014$ & Ficus microcarpa & Lam Tsuen & Non OVT & Yes \\
\hline Tree029 & $06 / 01 / 2014$ & Ficus microcarpa & Tin Sam Garden & LCSD ST/13 & Yes \\
\hline Tree030 & $06 / 01 / 2014$ & Ficus microcarpa & Pak Fuk Children's Playground & LCSD N/38 & Yes \\
\hline Tree031 & $06 / 01 / 2014$ & Ficus microcarpa & Shui Mei Village Playground & LCSD YL/6 & Yes \\
\hline Tree032 & $06 / 01 / 2014$ & Ficus microcarpa & Tuen Mun Park & LCSD TM $/ 5$ & Yes \\
\hline Tree033 & $13 / 12 / 2013$ & Phoenix canariensis & Magic road at Penny's Bay & Non OVT & No \\
\hline Tree034 & $15 / 01 / 2014$ & Ficus microcarpa & Essex Crescent Rest Garden & $\mathrm{LCSD} \mathrm{KC/3}$ & No \\
\hline Tree035 & $15 / 01 / 2014$ & Ficus microcarpa & Essex Crescent Rest Garden & LCSD KC/4 & No \\
\hline Tree036 & $23 / 01 / 2014$ & Ficus microcarpa & Caine Road near Ladder Street & $\mathrm{LCSD}$ CW/32 & No \\
\hline Tree037 & $23 / 01 / 2014$ & Ficus microcarpa & Caine Road near Ladder Street & $\mathrm{LCSD}$ CW/33 & No \\
\hline Tree040 & $10 / 02 / 2014$ & Ficus microcarpa & Cemetery beside Stubbs Road & Non OVT & Yes \\
\hline Tree041 & $14 / 02 / 2014$ & Gleditsia fera & Victoria Park & LCSD E/36 & No \\
\hline
\end{tabular}

*Tree 005 and Tree 039 were the same tree that was sampled twice in different days

${ }^{\#}$ Tree006, Tree 028 and Tree 038 were the same tree that was sampled trice in different days ${ }^{\triangle}$ OVT: old and valuable tree 


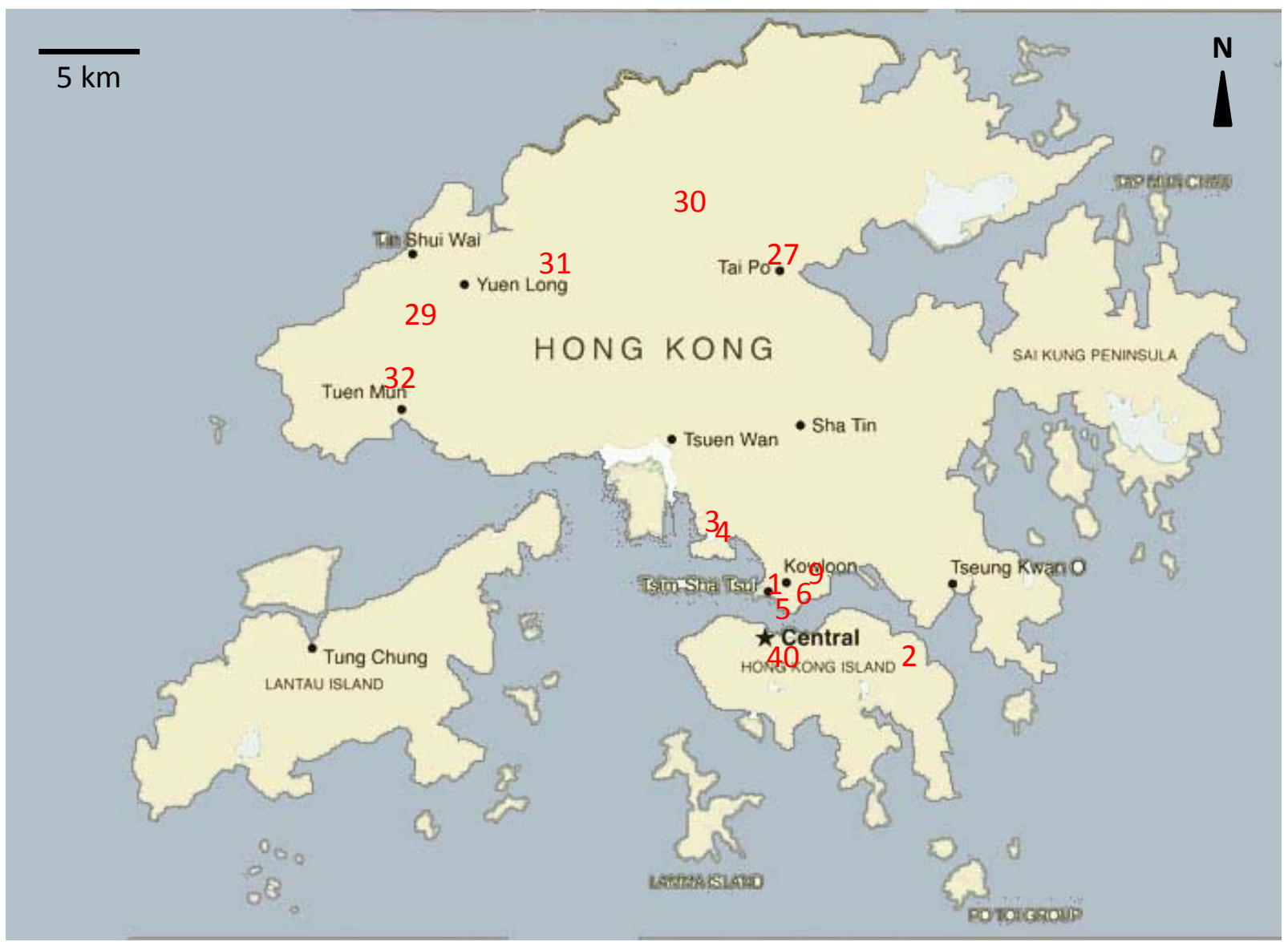

Figure 1. Sketch map indicating locations of trees infected with Phellinus noxius in Hong Kong. The Arabic numbers in red are the codes of the diseased trees infected with $P$. noxius, indicating the approximate locations of the trees on the map. The detailed information about the trees are listed in Table 1.

\subsection{The Occurrence of Phellinus Noxius in Soils}

In Kowloon Park, two trees with 15 m apart were confirmed positive for infection by $P$. noxius before. One of them was dead and had been removed. In this study, soils between the dead tree and the standing diseased tree (i.e. Tree006) were assayed. Eight of the nine samples collected were pos itive $w$ hen the ge nomic DNA was tested with the specific primer pair $\mathrm{PN}-1 \mathrm{~F} /$ PN-2R (data not shown), suggesting the eight samples contained $P$. noxius. T hree of the pos itive s amples were selected for constructing clone library and all of them were later confirmed to contain P. noxius (Figure 3 ). Most of the sequences acquired from the soils were related to the sequences from the di seased tree (they all fell into Clade 1) to support the association of pathogen identity between soil and trees growing in the soil. B ut one s equence of the s oils fell into C lade 3 that did not contain sequences from Tree006.

Through qua ntitative $r$ eal-time $P$ CR, $t$ he abu n- dances of P. noxius in soils between the dead tree and the diseased tree were quantified. The abundances of $P$. noxius ITS gene copies were between $1.5 \times 10^{4}$ and $2.7 \times 10^{5}$ gene copi es $\mathrm{g}^{-1}$ soil for the eight of the nine samples ( Figure 4 ). H owever, no c lear $t$ rend in the abundance of $P$. noxius was found $f$ or the s oils b etween the two trees.

Another $5 \mathrm{~s}$ oils under trees that w ere not infected with $P$. noxius were col lected for $t$ esting the oc currence of $P$. noxius. Two soils were under Tree008 and Tree036, w hich $\mathrm{w}$ ere not $\mathrm{i}$ nfected $\mathrm{w}$ ith $P$. noxius through molecular a nalysis. $\mathrm{T}$ he ot her $\mathrm{t}$ hree $\mathrm{s}$ oils (HKU s oill, HKU soil2 and HKU s oil3) we re collected from $t$ hree he althy $t$ rees on $\mathrm{c}$ ampus of $\mathrm{T}$ he University of Hong Kong. The soil under Tree036 and two soils on campus of The University of Hong Kong (HKU s oil2 and HKU s oil3) w ere c onfirmed to c ontain $P$. noxius with molecular analysis (Figure 2). The other $\mathrm{t}$ wo s oils ( soil unde $\mathrm{r}$ Tree008 a nd H KU s oil1) were tested negative (data not shown), indicating no $P$. 

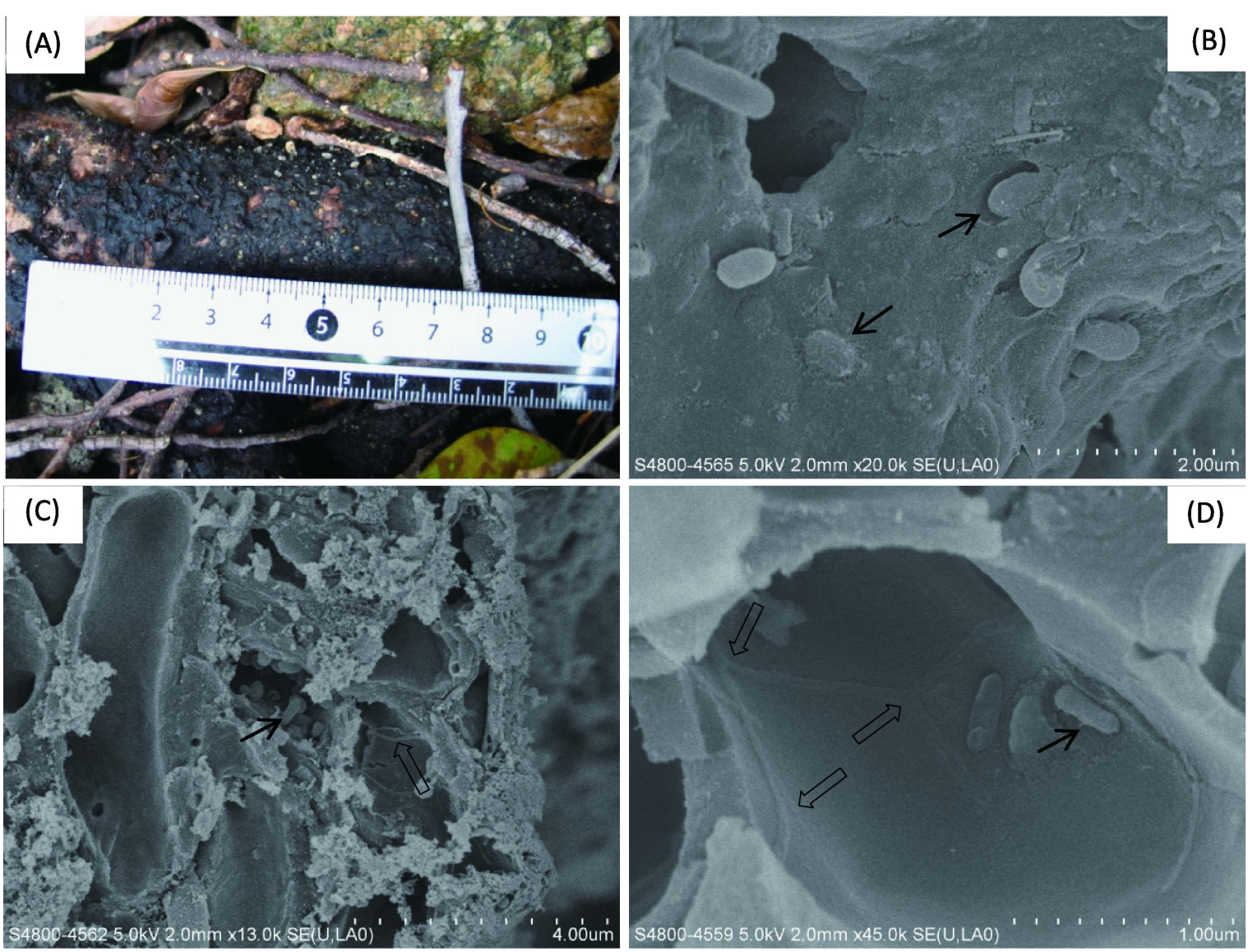

Figure 2. Symptoms of brown root rot caused by Phellinus noxius (A) and ultrastructure of diseased tissue (B, C, D). Picture (A) shows the symptoms of the root infected with P. noxius collected from Tree040; picture (B) shows the surface of mycelial mat; pictures $(\mathbf{C})$ and $(\mathbf{D})$ show the inner part of diseased root $(\Rightarrow$ indicates hyphae, $\rightarrow$ indicates bacteria that co-occurred in the diseased tissue).

noxius occurred in these two soils. These results show that the pathogen $P$. noxius is widely occurring in soils and the soil may be an important reservoir for its survival and infection.

\section{Discussion}

\subsection{Molecular Technique for Phellinus Noxius Di- agnosis}

Traditional approach t o i dentify $P$. noxius involves observing s ymptoms i n c ombination $\mathrm{w}$ ith $\mathrm{c}$ ulturing and i solating the pa thogens on agar plates ${ }^{[3,14]}$. More convincingly, researchers ut ilized the i solated $p$ athogen $t$ o $t$ est pa thogenicity according $t$ o t he K och's Postulates ${ }^{[2,18]}$. H owever, t he $\mathrm{c}$ ulturing procedure is usually time-consuming and t edious, $w$ hich i s not practical for quick diagnosis when confirmation is the first key information in need before a decision can be made accordingly on s ubsequent $h$ andling. The c onventional diagnosis can be simplified by omitting pa- thogenicity te st to save ti me, but it s till ne eds about two weeks to culture $P$. noxius on the defined medium agar $\mathrm{pl}$ ates. $\mathrm{M}$ oreover, $\mathrm{t}$ he $\mathrm{s}$ implified conventional diagnosis is neither sensitive nor specific enough because of the sample size on agar plates and also the selectivity of the medium composition.

Molecular approach is a quick and accurate way to identify $P$. noxius ${ }^{[25,26]}$. When the tissue is infected with the same type of $P$. noxius, all the sequences of the PCR amplified products are identical and thus can be sequenced directly. The whole process of diagnosis normally takes only two days to reach a final conclusion. When the tis sue is infected with more than two types of $P$. noxius, a clone library can be built for the PCR amplified ITS fragments, which will take about a total of one week to achieve a final conclusion. Thus, the molecular approach can shorten the time of diagnosis, which makes it a practical way for diagnosis of this pathogen. Mor eover, molecular approach is se nsitive, which can detect the pathogen at very low abundance 


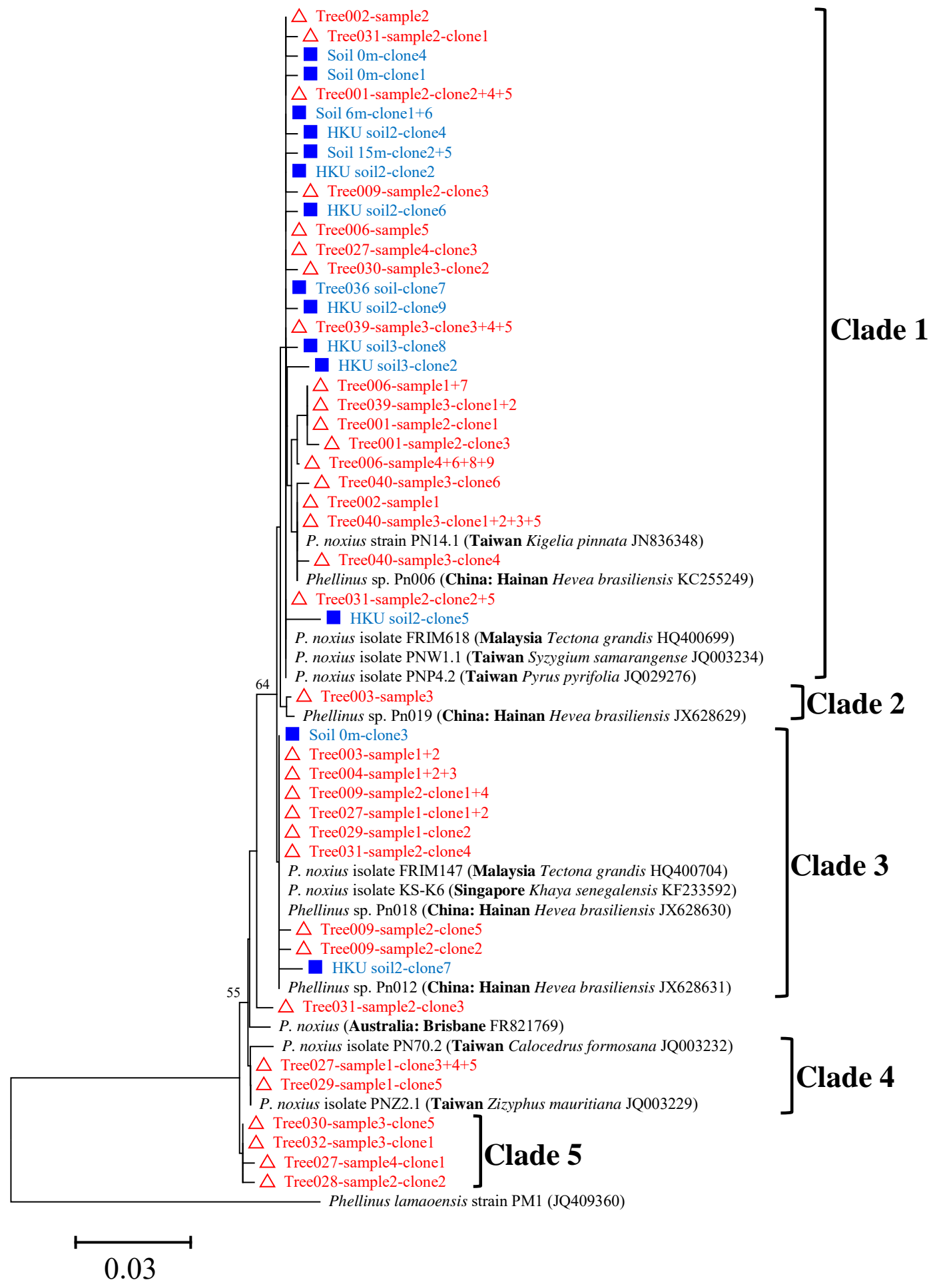

Figure 3. Phylogenetic tree of Phellinus noxius based on rDNA internal transcribed spacer(ITS) sequences retrieved from trees and soils in subtropical Hong Kong. The phylogenetic tree was reconstructed based on ITS sequences of 360/368 nucleotides. The corresponding sequence of Phellinus lamaoensis was used as the out group. If more than two identical sequences existed in one individual sample, only one sequence was used for phylogenetic analysis. For the reference sequences acquired from the GenBank data, the collection location, host, and accession number in the GenBank were indicated in the parentheses. The phylogenetic tree was constructed with the neighbor-joining method with 1000 bootstrapping to estimate the confidence of the tree topologies. Bootstrap values $(>50 \%)$ are indicated at the branch points. The scale bar represents 0.03 sequence divergence. The open triangles $(\Delta)$ in red represent tree samples, while the closed squares $(\square)$ in blue represent the soil samples. 


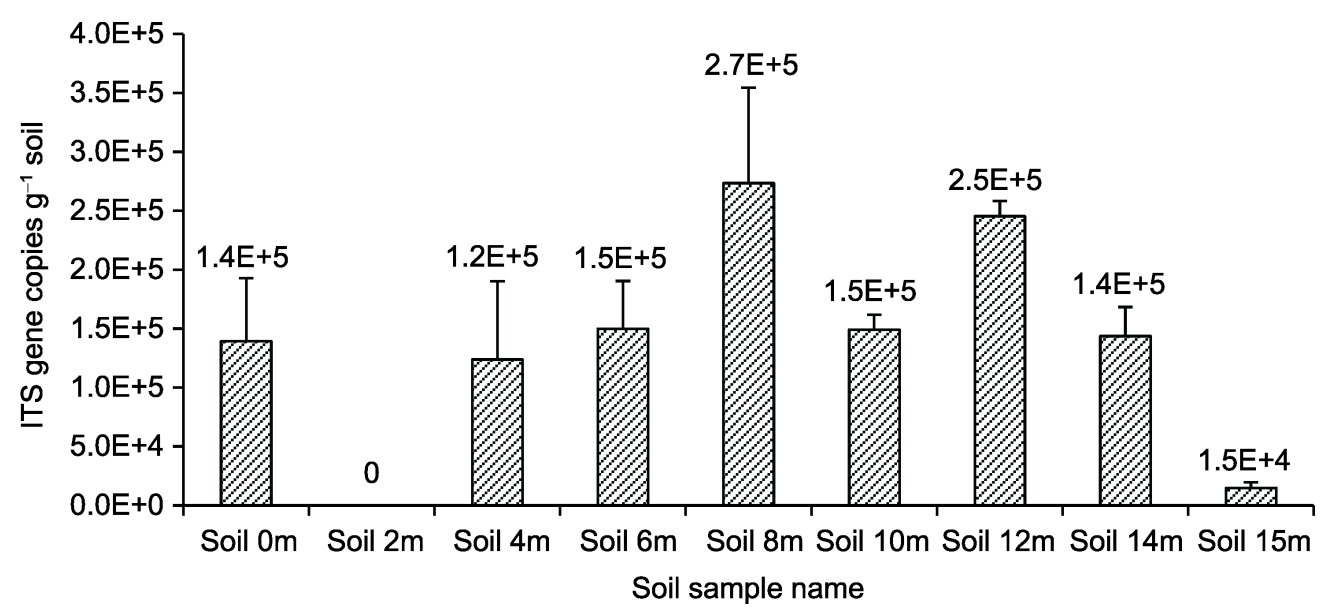

Figure 4. Internal transcribed spacer (ITS) gene copy numbers of soils between a dead tree and a diseased tree caused by $P$. noxius. The dead tree had been removed before the soils were collected. The two trees were $15 \mathrm{~m}$ apart and soils between the two trees were collected every $2 \mathrm{~m}$. The soil names indicate the distances from the dead tree.

from co mplex matrices of $\mathrm{s}$ amples. $\mathrm{T}$ his $\mathrm{m}$ akes it possible to i dentify brown root rot at its e arly phase when no obvi ous symptoms a ppear and the pa thogen loading is low. The e arly di agnosis is ve ry important for timely treatment and management. Traditional diagnosis, how ever, d oes not pos sess this priority f eatures because when symptoms are obvious, the tree is usually s eriously infected b y $P$. noxius and effective treatments a re virtually not a vailable ${ }^{[2,33]}$. In the present study, we analyzed 38 suspected trees and found 13 trees of them were po sitive for infection with $P$. noxius, suggesting that symptom observation can only serve as an auxiliary means for accurate diagnosis and for this particular detection, a $66 \%$ incorrect diagnosis was $r$ esulted $w$ hen only s ymptom obs ervation was applied.

\subsection{Dissemination Mechanism of Phellinus noxius}

Despite $P$. noxius has been discovered for more than 8 decades $^{[1]}$, no a greement has been reached on the mechanism of $P$. noxius dissemination in ecosystems. The dominant hypothesis is that $P$. noxius spread through root-to-root contact ${ }^{[2]}$. One reason is that infected soils and $t$ issues $c$ ould $l$ ead $t$ o $t$ he $f$ urther infection i $n$ healthy plants, which has been confirmed through experiments ${ }^{[13]}$. Another reason is that when one tree was affected $w$ ith $t$ his $p$ athogen, $s$ ome $s$ urrounding $t$ ree/ trees might a lso be inf ected later ${ }^{[3]}$. $\mathrm{T}$ his $\mathrm{h}$ ypothesis ruled o ut that airborne s pores s preading is the main approach of dissemination because basidiocarps are rarely found in natural ecosystems ${ }^{[2]}$.

In the pr esent $\mathrm{s}$ tudy, how ever, a 11 e vidence s uggested that $P$. noxius reside in soils as a reservoir for infection a nd pos sible s pread. F irstly, the di seased trees ca used by $P$. noxius were di stributed separately all ove $r \mathrm{H}$ ong K ong (Figure 1), s uggesting that they were not infected through a single source, because if so, the diseased trees should be infected by one type of $P$. noxius. Moreover, $P$. noxius has been reported in many countries and different continents in tropical and subtropical regions, w hich i ndicated it i s i mpossible that $P$. noxius spread only through root-to-root contact in nature and human may facilitate the spread of this pathogen $t$ hrough $t$ ransport of s eedlings 1 egally and illegally $^{[2]}$. This hypothesis needs further test to prove the mechanisms involved.

Secondly, a single diseased tree contains clones of $P$. noxius belonging to di fferent $\mathrm{c}$ lades of the ph ylogenetic tree (Figure 3), suggesting that the diseased tree was infected by different clones of $P$. noxius simultaneously or at di fferent $t$ imes. The pos sible reas on is that the tree was infected by the pathogens in soils as the pa thogens $w$ ere de tected in a ll s oil s amples $r$ egardless of the tree infection in this study and the microbial community is complex. In addition, our study also $s$ howed that di seased trees in separate $\mathrm{s}$ ites $\mathrm{c}$ an have $t$ he similar ty pe of $P$. noxius, s uggesting that these $P$. noxius might $\mathrm{come}$ from the $\mathrm{s}$ ame origin or source. A s the di seased trees are s eparated distantly from each other, the spread of this pathogen might be through human or air transport of soil and spores. This viewpoint is a lso in line $w$ ith the $f$ act that di seased trees in different countries have the same type of $P$. noxius (Figure 3 ).

Thirdly, $P$. noxius was de tected in the soils grown with the he althy $t$ rees in this s tudy (Figure 3 ), s ug- 
gesting this pathogen in the soils did not $\mathrm{c}$ ome from the trees. When examining the occurrence of $P$. noxius in the soils between a dead tree and an infected one, eight of the nine soil samples between these two trees contained P. noxius (Figure 4). Then a que stion rose: was $P$. noxius in the soils really from the infected trees or the ot her w ay a round? We c ould not a nswer this question directly. Instead, we further examined $5 \mathrm{~s}$ oil samples grown $w$ ith he althy $t$ rees di stributed in di fferent 1 ocation in $\mathrm{H}$ ong $\mathrm{K}$ ong a nd three of the five soils te sted positive for $P$. noxius, s uggesting the pathogen is c ommonly r esiding in the s oils. We hy pothesize that the more plausible dissemination way of the pa thogen o ver a 1 ong di stance is through the spread of s oil particles c ontaining the s pores or $h \mathrm{y}$ phae as the infection of $P$. noxius is always on roots or in the lower part of the trunk of trees. Thus, soils are more 1 ikely the major s ource of $P$. noxius to infect trees when root tips are in contact with the pathogens in spores or vegetative forms.

Although $P$. noxius may s pread by ai rborne routes in na tural systems, di rect c ontact be tween the pa thogen and roots a nd r oot-to-root is the key i nitial s tep before effective infection can be realized. Airborne spores might widely exist in soils, but only under selective conditions these spores can infect the trees and germinate. $F$ or e xample, the young root $t$ ips of $t$ he trees a re most likely the entry point of infection because matured roots do not allow pe netration by germinated spores unless physical damages are available. Once a t ree is infected, $P$. noxius might infect ot her trees t hrough r oot-to-root $\mathrm{c}$ ontact $\mathrm{w}$ hen extension of roots makes this possible. It is a normal phenomenon that trees are infected frequently in patches in ecosystems most like ly due to the a vailability of pa thogens and also the root-to-root contacts.

In summary, a molecular based testing was tested and obs ervation can overestimate the brown root rot by as high as $66 \%$. P. noxius found on various trees in Hong Kong may be or iginated from widely different sources.

\section{Conflict of Interest and Funding}

No conflict of interest is reported by the authors. This project was supported by Development Bureau of Hong Kong SAR Government (Contract No. WQ/027/13; Q072/2010). T he vi ews e xpressed a re $t$ hose of $t$ he authors and no implication for the role of government on the information reported should be made.

\section{Acknowledgements}

We would like to thank the arborist Mr. Ching Wai for assisting sample collection in the field. We are grateful to Ms. Kelly Lau for support in laboratory work.

\section{References}

1. Corner E J H, 1932, The identification of the brown-root fungus. The Gardens' Bulletin, Straits Settlements, vol.5: 317-350.

2. Ann P-J, Chang T-T and Ko W-H, 2002, Phellinus noxius brown root rot of fruit and ornamental trees in Taiwan. Plant Disease, vol.86(8).

http://dx.doi.org/10.1094/PDIS.2002.86.8.820.

3. Sahashi N, A kiba M, I shihara M, et al. 2012, Br own root $r$ ot of $t$ rees $\mathrm{c}$ aused by Phellinus noxius in the Ryukyu Islands, subtropical areas of Japan. Forest Pathology, vol.42(5): 353-361. http://dx.doi.org/10.1111/j.1439-0329.2012.00767.x.

4. Sahashi N, Akiba M, Ishihara M, et al. 2007, First report of the brown root rot disease caused by Phellinus noxius, its di stribution and ne wly recorded host pl ants in the Amami I slands, s outhern Japan. Forest Pathology, vol.37(3): 167-173.

http://dx.doi.org/10.1111/j.1439-0329.2007.00491.x.

5. Bolland L, 1984, Phellinus noxius: cause of a significant root-rot in Queensland hoop pine plantations. Australian Forestry, vol.47(1): 2-10.

http://dx.doi.org/10.1080/00049158.1984.10675972.

6. Chang T T and Yang W W, 1998. Phellinus noxius in Taiwan: distribution, host plants and the $\mathrm{pH}$ and texture of the rhizosphere soils of infected hosts. Mycological Research, vol.102(9): 1085-1088.

http://dx.doi.org/10.1017/S0953756297005571.

7. Singh S, Bola I and Kumar J, 1980, Diseases of plantation trees in Fiji islands I. Brown root rot of mahogany (Swietenia macrophylla King). Indian Forester, vol.106: 526-532.

8. Nicole M, Nandris D, Geiger J-P, et al. 1985, Variability among African populations of Rigidoporus lignosus and Phellinus noxius. European Journal of Forest Pathology, vol.15(5-6): 293-300.

http://dx.doi.org/10.1111/j.1439-0329.1985.tb01102.x.

9. Neil P, 19 86, A pr eliminary not e o n Phellinus noxius root rot of Cordia alliodora plantings in Vanuatu. European Journal of Forest Pathology, vol.16(5-6): 274-280. http://dx.doi.org/ 10.1111/j.1439-0329.1986.tb00192.x.

10. Nandris D, Nicole M and Geiger J-P, 1987. Variation in virulence a mong Rigidoporus lignosus and Phellinus noxius isolates from West Africa. European Journal of Forest Pathology, vol.17(4-5): 271-281. http://dx.doi.org/10.1111/j.1439-0329.1987.tb01026.x. 
11. Ann P-J and Ko W-H, 1992, Decline of l ongan trees: association with brown $\mathrm{r}$ oot $\mathrm{r}$ ot ca used $\mathrm{b}$ y Phellinus noxius. Plant Pathology Bulletin, vol.1: 19-25.

12. Abe Y, Kobayashi T, Onuki M, et al. 1995, Brown root rot of trees caused by Phellinus noxius in windbreaks on Ishigaki i sland, J apan: incidence of disease, $\mathrm{p}$ athogen and artificial inoculation. Annals of the Phytopathological Society of Japan, vol.61: 425-33.

http://dx.doi.org/10.3186/jjphytopath.61.425.

13. Chang T-T, 1995, Decline of nine tree species associated with brown root rot caused by Phellinus noxius in Ta iwan. Plant Disease, vol.79(9): 962-965. http://dx.doi.org/10.1094/PD-79-0962.

14. Brooks F E, 2002, Brown root rot disease in American Samoa's tropical rain forests. Pacific Science, vol.56(4): 377-387. http://dx.doi.org/10.1353/psc.2002.0031.

15. Supriadi E, Adhi M, Wahyuno D, et al. 2004, Brown root rot disease of cashew in West Nusa Tenggara: distribution and its causal organism. Indonesian Journal of Agricultural Sciences, vol.5(1): 32-36.

16. Farid A M, Lee S, Maziah Z, et al. 2005, Basal root rot, a ne w di sease of t eak (Tectona grandis) in M alaysia caused by Phellinus noxius. Malaysian Journal of Microbiology, vol.1(2): 40-45.

17. Farid A M, Lee S S, Rosli H M, et al. 2005, Incidence of teak basal root rot caused by Phellinus noxius in Malaysia. Australasian Plant Pathology, vol. 34(2): 277-278.

18. Sahashi N, Akiba M, Ishihara M, et al. 2010, Cross inoculation tests with Phellinus noxius isolates from nine different host plants in the Ryukyu Islands, southwestern Japan. Plant Disease, vol.94(3): 358-360.

http://dx.doi.org/10.1094/PDIS-94-3-0358.

19. Wu J, Peng S L, Zhao H B, et al. 2011, Selection of species resistant to the wood rot fungus Phellinus noxius. European Journal of Plant Pathology, vol.130(4): 463-467. http://dx.doi.org/10.1007/s10658-011-9774-6.

20. Chang T T, 1995, A selective medium for Phellinus noxius. European Journal of Forest Pathology, vol.25(4): 185-190. http://dx.doi.org/10.1111/j.1439-0329.1995.tb01002.x.

21. Pegler D N and Waterston J M, 1968, Phellinus noxius. No. 195, in Descriptions of Pathogenic Fungi and Bacteria. Kew, England: Commonwealth Mycological Institute.

22. Schwarze FWMR, Jauss F, Spencer C, et al. 2012, Evaluation of an antagonistic Trichoderma strain for reducing the rate of wood decomposition by the white rot fungus Phellinus noxius. Biological Control, vol.61(2): 160-168. http://dx.doi.org/10.1016/j.biocontrol.2012.01.016.

23. Chang T T and Chang R J, 1999, Generation of volatile ammonia from ur ea f ungicidal to Phellinus noxius in infested wood in soil under controlled conditions. Plant Pathology, vol.48(3): 337-344.

http://dx.doi.org/10.1046/j.1365-3059.1999.00349.x.

24. Chang T-T, 1996, Survival of Phellinus noxius in s oil and in the root s of de ad ho st $\mathrm{pl}$ ants. Phytopathology, vol.86: 272-276.

http://dx.doi.org/10.1094/Phyto-86-272.

25. Tsai J N, Hsieh W H, Ann P J, et al. 2007, Development of specific primers for Phellinus noxius. Plant Pathology Bulletin, vol.16: 193-202.

26. Chang T T, Fu C-X and Wu M-L, 200 9. Brown Root Disease Testing and Prevention. Council of Agriculture, Executive Yuan, Forestry Bureau: R.O.C.

27. Ding S, Hu H and Gu J-D, 2015. Analysis of fungi colonizing the wood sticks of Chinese fir (Cunninghamia lanceolata) in subtropical urban soil grown with Ficus microcarpa trees. International Journal of Environmental Science and Technology, vol.12(12). http://dx.doi.org/10.1007/s13762-015-0802-5.

28. Wang Y-F, Zhang F-Q and Gu J-D, 2014, Improvement of D GGE ana lysis by modifications of P CR p rotocols for analysis of microbial community members with low abundance. Applied Microbiology and Biotechnology, vol. 98(12): 5655-5663. http://dx.doi.org/10.1007/s00253-014-5734-3.

29. Wang Y-F and Gu J-D, 2014, Ef fects of al lylthiourea, salinity and $\mathrm{pH}$ on ammonia/ammonium-oxidizing prokaryotes in mangrove sediment incubated in laboratory microcosms. Applied Microbiology and Biotechnology, vol.98(7): 3257-3274.

http://dx.doi.org/10.1007/s00253-013-5399-3.

30. Altschul S F, Gish W, Miller W, et al. 1990, Basic local alignment s earch t ool. Journal of Molecular Biology, vol.215: 403-410.

31. Tamura K, Peterson D, Peterson N, et al. 2011, MEGA5: molecular evol utionary ge netics ana lysis using maximum 1 ikelihood, evol utionary distance, an d maximum parsimony methods. Molecular Biology and Evolution, vol.28: 2731-2739. http://dx.doi.org/10.1093/molbev/msr121.

32. Gu J-D, Mitton D B, Ford T E, et al. 1998, Microbial degradation of polymeric coatings measured by electrochemical impedance spectroscopy. Biodegradation, vol.9: 39-45.

33. Ann P, Lee H and Huang T, 1999, Brown root rot of 10 species of fruit trees caused by Phellinus noxius in Taiwan. Plant Disease, vol.83(8): 746-750. http://dx.doi.org/10.1094/PDIS.1999.83.8.746. 